\title{
TOWARDS MS1900:2014 QUALITY MANAGEMENT SYSTEM FROM ISLAMIC PERSPECTIVE: A CASE STUDY AT MACS
}

\author{
Arbain Sarion ${ }^{1}$, Ummi Salwa Ahmad Bustamam², Amir Shaharudin² \\ ${ }^{1}$ Research Assistant, Faculty of Economics and Muamalat, Universiti Sains Islam Malaysia (USIM). \\ ${ }^{2}$ Lecturers, Faculty of Economics and Muamalat, Universiti Sains Islam Malaysia.
}

Corresponding author: arbainsarion@gmail.com

\section{Article history}

Received: 2014-10-30

Received in revised form: 2015-02-05

Accepted: 2015-02-05

\begin{abstract}
This study explores strategies implemented by applicants towards achieving a quality management system from Islamic perspective, MS1900:2014 which ultimately will assist other organizations in pursuing the similar standard. A case study approach was used as methodology for the study. A semi-structured interview was carried out to answer the research question. The interview was conducted with Manager of Service Monitoring Division at Malaysian Airports Consultancy Services (MACS). The study found that there are several strategies implemented by MACS in accomplishment of the standard. Those strategies can be divided into two phases. Seeking a support and authorization from top management is the initial point for pursuing standards management system. A specific department or unit should be setting up in order to strategically obtaining the standard. This study focused the strategy implemented by a unique research unit in getting the MS1900:2014 which might be inadequate to be adopted by other organizations.
\end{abstract}

Keywords: Quality Management System from Islamic Perspective, MS1900:2014, Case Study, Business Strategy 


\subsection{INTRODUCTION}

Quality management system has been established in Malaysia as one of the Government's agenda to provide a respectable public service. Along the way, many programs have been introduced such as Total Quality Management (TQM), Quality Control Circle (QCC), Quality Assurance Unit, Strategic Management and Customer Charter. Furthermore, since 1996, ISO 9000 has been established in public services in Malaysia (Siddiquee, 2006).

Malaysia also practices ISO 9001 which covers the public and private service introduced by the International Organization Standardization (ISO Geneva). As a Muslim-majority country, Malaysia is heading further by introducing and implementing the MS1900:2005, a quality management system from shariah perspective (Che Pa et al., 2010). This standard was developed based on ISO 9001, an international practice standard and was subjected to its first revision on year 2014 which now being recognised as MS1900:2014. This standard requires organization to have a comprehensive quality management system in order to accommodate customer needs, to fulfil the requirement of a quality product/service, to enhance the effectiveness and productivity as well as to reduce the operational costs. These requirements are value added from the ISO 9001 and are aligned to the shariah perspectives. As stated by the Departments of Standard Malaysia (2005), the objectives of MS1900:2014 are:-

1. To implant the shariah in quality management system with emphasis on management through value.

2. To improve the effectiveness and efficiency through noble universal values in all levels of organization.

3. To upsurge the practice of shariah compliance and increase the confidence level among the Muslims and stakeholders.

The value of MS 1900:2014 is universal and although its compliance is from the Islamic perspective, its universal values is widely accepted. For example improving work quality and performance, as well as proper and timely delivery. All of these are not in conflict with universal values and general features of the other religions (Bernama, 2008). On top of that, Syed Azauddin (2005) lists three reasons of having this standard to a company. These are benchmarking, ensuring uniformity and growing the organization. However, the reason of standard obtainment would be subjective in regards to the organization's motives. As being found by Sun (2000), the TQM criteria (or enablers) such as quality leadership, human resource development, quality information, etc. contributes to the improvement of customer satisfaction and business performance.

In Islam, quality has been emphasized a long time ago by Al-Quran and hadith;

"He sends down from the sky, rain, and valleys flow according to their capacity, and the torrent carries rising foam. And from that [ore] which they heat in the fire, desiring adornments and utensils, is foam like it. Thus Allah presents [the example of] truth and falsehood. As for the foam, it vanishes, [being] cast off; but as for that which benefits the people, it remains on the earth. Thus does Allah present examples."

(Al-Ra'd, 13: 17)

"You, O community of Muhammad (s), are the best community brought forth, manifested, to men, according to God's knowledge, enjoining decency, and forbidding indecency, and believing in God. Had the People of the Scripture believed, it, their belief, would have been better for them; some of them are believers, may God be pleased with him and his companions; but most of them, the disbelievers, are wicked."

(ali-Imran, 3:110)

"Truly those who believe and perform righteous deeds - indeed We do not leave the reward of those of good deeds to go to waste (this [last] sentence is the predicate of the [previous] inna'lladhina, 'truly those who', and in it an overt identification [of the recipients of the reward] 
has replaced the [would-be] pronominalisation, in other words, it is 'their reward' [which shall not be left to go to waste], and We will reward them with what it [the reward of good-doers] comprises)."

(al-Kahfi, 18:30)

A hadith by Rasulullah S.A.W narrated by Imam al-Bayhaqi, "Verily, Allah loves those who, when doing something, he does it with the best. He loves the act and also loves people who does it."

The above verses and hadith have clearly shown that Allah emphasized the importance of giving the best quality in any matter. Moreover, Allah has created men as the best creature to obey Him.

\subsection{LITERATURE REVIEW}

According to Bernama, in 2008, five companies have been awarded the MS1900:2014. They are Natural Wellness Sdn Bhd, Century Total Logistic Sdn Bhd, Takaful Ikhlas, PNB Darby Park and Pusat Zakat Melaka. In 2011, another 10 organisations have received this standard. They were Syarikat PNB Ilham Resort, Universiti Sains Islam Malaysia (Jabatan Pembangunan dan Pengurusan Fasiliti), Universiti Tenaga Nasional Sdn Bhd (UNITEN), Penang Port Sdn Bhd, Jabatan Kehakiman Syariah Perak, Kolej Komuniti Gerik, Sindora Berhad, Tabung Baitulmal Sarawak, Jabatan Wakaf, Zakat dan Haji and KFC Manufacturing Sdn Bhd (Group Logistic Division). In 2014, however, according to Malaysian Certified, there are 29 organizations who have received the MS1900:2014 from SIRIM Berhad (formely known as Standards and Industrial Research Institute of Malaysia). Therefore, there are increment in number of organizations who have been accredited by MS1900:2014.

The idea of MS1900:2014 was mooted by Tun Ahmad Sarji in 2003. During that time, he was a former chairman of SIRIM Bhd. He said that the emergence of MS1900:2014 is due to the absence of standard based on Islamic guidelines that could be made as a yardstick or gauge to evaluate the efficiency of the organization. In addition, according to him, the management did not give serious attention to the focus and appreciation of Islamic values. Tun Ahmad Sarji asserted that MS1900:2014 will ensure the continuous company's quality of product and service. Apart from that, the implementation of MS1900:2014 can be seen as part of business strategy to win Muslim consumer market while strengthening the working culture in organizations and companies (Bernama, 2010).

As mentioned by Hanida (2013), MS1900:2014 is developed based on ISO 9001: 2008. The main idea of MS1900: 2014 is a structured system to assist organization to deliver products and services, meeting customers' requirements, compliance to regulatory requirements and comply with the shariah requirements. In addition to that, MS1900: 2014 inculcate and put into practice the Islamic values system into the organization daily operations. There are three principles behind MS1900: 2005. Organization shall strictly adhere to the principles of halal and haram as well as the principles of Muamalat. The implementation of MS1900:2014 also ensures an organization to operate based on the "objective of shariah (maqasid al-shariah)". One of the requirements stated in the standard is compliance to shariah requirements in financial management, human resources management, procurement procedures, production and marketing.

On the issue of enforcement, Hanida (2013) highlighted that implementing this standard for an organization is made voluntary. However, SIRIM's Shariah Advisor Board (SAC) suggested that the implementation of this standard must compulsory. The board also proposed this matter to be tabled in Parliament as the case of Halal Act. However, due to some limitations and considering SIRIM is not an authority body, this proposal remains unattended.

There are several reasons of implementation of MS1900: 2014 standard in an organisation. As stated in the article titled Importance of Standards (2014), having this standard makes life safer, healthier and do assist people and organisation by providing a benchmark against which performance can be judged. Standard also gives benefit to organisation as it can reduce cost and time whereby organisation may focus on the R\&D for new product. "Some customer will only buy from suppliers that comply with certain standards (often the case of public sector contracts), standard-compliance can provide competitive advantage too, it could be a deciding factor when a buyer has to choose between two comparable suppliers" (Reliancestandards.co.uk, 2014). 


\subsection{METHODOLOGY}

This study is conducted by utilizing a case study method in order to study in-depth about the research question (Yin, 2009). This study is sought to understand of why and how business organizations crafting strategy towards achieving the MS1900:2014 and eventually to gain business competitiveness. Primary data were sought through semi-structured interviews with three main organizations which are the standard body of SIRIM Berhad, the current holder of the standard and also with a company who is in the process of obtaining the MS1900:2014. Besides that, secondary data such as company documents, newspapers and articles were also obtained to support the input from the interviewees.

For this particular paper, data used in this paper was gained from an interview conducted with Manager of Service Monitoring Division at Malaysian Airports Consultancy Services (MACS). This paper highlights Puan Roslina's experience as the Division Manager who responsible for managing the MS1900:2014's application and auditing process. Puan Roslina's experience is undeniably important since she is the person in-charge throughout the application process. The access that the researchers gained in getting her invaluable experiences is very much appreciated. This is especially when there are a very limited number of companies that have been certified with MS1900:2014.

\subsection{FINDINGS}

An action is strategic when it allows a firm to become better than its competitors, and when this "competitive advantage" can be sustained (Mazzucato, 2002). According to Michael E. Porter (1996), strategy is the creation of a unique and valuable position, involving a different set of activities. In order to maintain in the industry, an organization shall have an outstanding strategy which will differentiate it from its competitors. Strategy will become vital when there are many players in the industry and firm with outstanding strategy will become the leader.

Despite of its size, MACS, a leader in consultancy industry, became the first consultancy firm that has been certified with MS1900:2014. With the intention of getting this standard as a value added and marketing strategy, MACS has prepared strategy towards getting this standard. As a result, after two years, they were awarded with MS1900:2014. This paper addresses about the strategies used by MACS towards getting the MS1900:2014. Those strategies will be divided into two phases. First, the strategy before the standard was awarded and the second phase is strategy after the standard was awarded. Both phases are important since the first strategies were used in order to get the standard while the second phase was used in order to sustain its dominion. It is important to realize that every certified organization will undergo an audit process every three years to renew MS1900:2014 certificate, thus it is important to have a strategic action for continuing the MS standard.

\subsection{First Phase: Strategy and planning towards getting MS1900:2014}

Planning is crucial in order to achieve goals and objectives. As being outlined by Fontaine and Ahmad (2011), planning is a process which deals with thinking that is directed towards the future. Planning is not a theoretical concept, and does not simply imply putting words and drawings on paper. Planning is a process of several aspects, such as actions, commitments, implementation of decisions, modifying and applying flexibility. In addition to this, there are four basic principles of planning from an Islamic perspective. These are; forward thinking based on past experiences, rational use of resources, consultation before decision making and applying fairness to others.

Apart from that, there are several well-known concepts introduced by Islam that can be applied on management process (planning, organising, leading and controlling), for instance, Shura and musyawarah. Shura has been practiced even during the time of Prophet Muhammad (PBUH). It was aimed at building a consensus that will benefit the community or the business that has to make decision. (Abdus, Kashif and Amna, 2010). Besides, musyawarah is usually be done while committee/project member gather to discuss certain issues and it ends with some decisions.

A verse in Qur'an that mentioned about Shura concept;

"And it was the mercy of God that you dealt gently with them (your followers): had you been harsh or thick of heart they would have dispersed from around you. So pardon them and ask (God) for their forgiveness and maintain Shura with them"

(Ali-Imran, 3: 159) 


\subsubsection{Seeking support and authorization from the top management}

This is basically the first step to be taken when a firm wanted to make some changes in their business. As a subsidiary company to Malaysian Airport Holdings Berhad (MAHB), MACS was bound with the parent company. Thus, the first strategy was to get support and approval from top management. This was critical stage whereby the company had to convince the top management members that were from various backgrounds. Anthony (1965) suggested that top management is responsible for the development and implementation of an organization's strategy. Lederer and Mendelow (1988) found that one of the reasons why top management refuses to recognize strategic impact of information system is due to their lack of awareness. In conjunction with this, MACS prepared the best proposal to convince top management as well as to assure they were aware of the importance of the certification. Every point to be proposed must come with a good reason and justification. According to Huber and Seiser (2001), there are two types of justifications; that are accounting and convincing. In this case, MACS used convincing justification whereby they persuade other decision makers to recognise that MS1900:2014 is the best standard management system and suggested to be adopted.

Boatright (2000) advocates an integrated approach to decision making in business that gives appropriate weight to each of three points of view: economic, legal and ethical. In this situation, MACS's concern is more on economic view as they highlight on the potential of positive business growth after being certified. It is vital to realize that MAHB is a large corporation and its top management team consist people from diverse background that also include Muslims and non-Muslims personnel. Therefore, MACS needs to prepare a very convincing proposal in order to gain approval from them especially from the non-Muslim Board of Directors (BOD). The presenter for the proposal should be very competent whereby he/she must be prepared for any question that will be asked by the BOD. "Justifying a decision is a quite complex cognitive process. It involves not only knowledge about the domain of decision, but also the construction of subjective theories about the specific values of other people" (Huber and Seiser, 2001).

\subsubsection{Preparing the organization to implement the MS1900:2014}

In order to get this certification, every person involves in the organisation should be in the same level understanding. Meaning that, they should give their commitment and cooperation along the process of getting the MS standard and maintain the commitment even after being certified. In the first place, it is important to ensure that everyone in the organization has a same mindset to achieve the same goal [to obtain MS1900:2014 and to sustain it]. According to Blackburn (1998), Einhorn and Hogarth (1981) and Pitz and Sachs (1984), within the context of decision making theory, mindset has been described as a set of assumptions which is established in the minds of people that creates a powerful incentive within themselves to continue to adopt and to accept prior choices. With regard to this matter, MACS first approach was to increase awareness among its staff about the MS1900:2014. By having this, staff will be aware and understand the company's objective, thus provide their cooperation and commitment.

\subsubsection{Providing attentiveness about MS1900:2014}

According to Endsley (1995), awareness is knowledge created through interaction between an agent and its environment- in simple terms, "knowing what is going on". Believe awareness as a principle of commitment, the first approach taken by MACS in their way of gaining staff commitment is giving awareness. They informed their staff about the standard so that their employees will understand about MS1900:2014 and objective of pursuing it. Supported by a clear objective, mission and vision of the firm, staff will understand, ultimately will give their support and commitment.

From a practical point of view, MACS is basically practiced strategic awareness in this project. Strategic awareness can be defined as "the ability to make an assessment of the total impact of any particular change. This means not only awareness of the immediate impact of any new development but also reflection on the longer term repercussions" (Gibb \& Scott, 1985).

With this awareness programs, the process of getting certificate will be easier and smooth. This is due to the cooperation given by the people (management and staff) in the firm. To illustrate, when Certification Body (CB) comes to perform audit, they can see the unanimous, togetherness and cooperation of the firm as a whole in getting the standard. This will give the firm some good point to be considered. 


\subsubsection{Getting commitment and cooperation from the internal organization}

After providing attentiveness about this standard, MACS expect commitment in return. As stated by Cooper (2006), managerial commitment can be defined as "engaging and maintaining behaviours that help others achieve a goal". Although this process takes time, it is worthwhile since the bigger business await, which is being certified by MS1900:2014. This can be considered as a strategy whereby MACS is very wise in planning and utilizing time. They gain top management authorization, followed by staff commitment then only they go for documentation and audit process.

Since this project can be considered as a huge project, planning should be spectacular and great. According to Snyder and Glueck (1980), planning is working out in broad outline the things that need to be done and the methods for doing them to accomplish the purpose set for the enterprise. In this case of MACS, there is a specific team for this project called Management System Unit. This unit handled everything about management system and implement the company's policy. Besides being mastermind for this project, they are being as implementer of the company's existing policy.

\subsubsection{Having a good relationship with the Certification Body (CB)}

SIRIM QAS is the only certification body for MS1900:2014 in Malaysia and MACS personnel has a good relationship with their auditors. They continue to develop such good relationship, as this wise strategy will provide an advantage to them to refer any issues related to the MS standard in the future. A good relationship will assist the applicant in terms of the auditing process. This is in line with what has been reported by Sherry (2013), "many supply chain problems begin and end with the customer-supplier relationship". The extent to which critical issues, wastes and cost drivers can be identified and mutually addressed depends heavily on the strength of the customersupplier relationship. Customer-supplier relationship quality can drive success.

What makes it even more strategic is that, Manager of Service Monitoring Division, Puan Roslina, she herself involved with SIRIM QAS as an external auditor. She participated in MS1900:2014 seminar and even joined the auditing process of other applicants. This benefited MACS as they would know the auditing process and understand the auditing need in order to avoid problems. Having knowledge as well as experience are very crucial in ensuring the certification process dunning smoothly. Supported by Patrick Sukind (1985) “...talent means nothing, while experience, acquired in humility and with hard work, means everything."

\subsection{Second Phase: Strategy after being awarded with MS1900:2014}

As mentioned earlier, this strategy is very important in order to assure the standard is maintained in the MACS Company. After three years being certified, re-certification audit will take place. Thus, to ensure company keep holding the standard, strategies should be taken into consideration. Discussed below are the strategies taken by MACS in order to maintain their awarded MS1900:2014 standard.

\subsubsection{Provide training}

After being awarded with MS1900:2014 by SIRIM QAS, MACS has been very concern with Islamic values, aligned with MS1900:2014 objective which is to implant the shariah in quality management system which emphasis on management through values. MACS's approach to inculcate Islamic values is by having training programs to their staff. They invite external person such as lecturer and motivator to give training to their employees. The training is basically about Islam, especially dos and don'ts. With the overarching content, MACS anticipates their employees could inculcate Islamic values in their work and life as the outcome from the training programs.

Training is basically a planned and organized process which develops a person's ability to perform a function in order to achieve a goal, (Hoff, 1970). Training is a process whereby a series of activities or operations designed to accomplish a specific change of result. Training usually continues over extended period. In this case of MACS, training is divided into two types. First is fard ain and second is shared value training.

Fard ain focuses on Muslim's obligation like prayer (Solah) while shared value training is more on management from the Islamic perspective. For instance, one of the shared value training topics that have been done by MACS is "Cooperation and adaptation in Islamic Perspective". During the programs, staffs are free to ask 
questions. This is a good platform whereby vague things will be unravelled. Sometimes there are some unclear things especially about Muamalat (Islamic transaction). By having such program, invited religious speakers will clarify those unclear issues from the Islamic perspective.

\subsubsection{Giving back to society}

As an appreciation, MACS decided to share it with society. They had a quality day with their staff cum a family day to acknowledge their staff's contribution. Besides that, MACS helped the less-fortunate people by doing "iftar jama'ie" (breaking fast together) at an orphanage. They believe that this is their responsibility to share and help less-fortunate people. This activity also can be considered as a Corporate Social Responsibility (CSR).

As defined by International Standardization Organization (ISO) and strategic advisory group, CSR is "a balanced approach for organizations to address economic, social and environmental issues in a way that aims to benefit people, communities and society." Companies with sound reputations not only for financial results but also for environmental and social contributions promise long-term sustainable growth.

Apart from that, CSR impacts a wide range of organizational activities including product manufacturing and integrity, marketing and advertising, selling practices and so forth. Thus, it is fair to conclude that CSR will bring a good image to MACS simultaneously. In other words, MACS will have a positive image concurrently convincing SIRIM QAS as a CB throughout the first three years (before re-certification audit).

\subsection{CONCLUSION}

As discussed, there are several strategies used by MACS in getting the MS standard. These include i) seeking a support and authorization from the top management, ii) getting the organization's readiness to adoption of MS1900:2014, iii) providing attentiveness about MS1900:2014, iv) getting commitment and cooperation from the internal organization and v) having a good relationship with Certification Body (CB). Those strategies could be adopted by the other potential applicant of MS1900:2014.

Apart from that, there are some strategies being implemented by MACS to maintain the MS standard certification. They claimed that, these strategies are important to avoid problems in the future. In a nutshell, both phases of strategies (before and after getting the MS standard) are important to be taken into account if an organization/firm intended to apply for MS1900:2014. The strategies used might be different from one certified company to another certified company. Discussed strategies above are used by Malaysian Airports Consultancy Services (MACS). With those strategies being executed, they are finally being certified after 2 years of process.

After being certified for about 2 years, MACS is growing now in their business. They claimed that the MS1900:2014 has actually provided positive impact for them in getting business tenders from both local and international market. For instance, they have been awarded a tender for upgrading Kuah Jetty, Langkawi, Kedah. Another big project is a tender from Doha for expanding their airport project, specifically in facility management, cleaning and operation. With this in mind, it is worthwhile to conclude that MS1900:2014 can be seen as part of business strategy to win Muslim consumer market while strengthening the working culture in organization and company. 


\section{REFERENCES}

Abdus, S., Kashif, U. and Amna, B. (2010). Islamic management model. African Journal of Business Management, 4(9), pp.1873-1882.

Anthony, R. (1965). Planning and control systems: a framework for analysis. Division of Research, Graduate School of Business Administration, Harvard University Boston, MA.

Bernama.(2008). MS 1900:2005 - Halal standard for quality management. Accessed from http://kpdnkk.bernama.com/news.php?id=367563\& on $9^{\text {th }}$ September 2012.

Boatright, J. (1995). Cases in Ethics and the Conduct of Business. Prentice Hall Englewood Cliffs, NJ.

Che Pa, B., Basir, S.A. \& Mohamed, S. (2010). Perlaksanaan siyasah syariyyah dalam pentadbiran di Malaysia. Jurnal Al-Tamaddun, 5, 57-72.

Cooper, D., Psychd, C. and Fiosh, C. (2006). The impact of management's commitment on employee behavior: A field study In: 7th Professional Development Conference \& Exhibition. Bahrain: 7th Professional Development Conference \& Exhibition.

Coughlan, R. (2005). Codes, values and justifications in the ethical decision-making process.Journal of Business Ethics, 59(1-2), pp.45-53.

Departments of Standard Malaysia. (2005). Quality management standard: Requirement from Islamic perspectives. Accessed from www.ipgperlis.edu.my/.../142-rujukan-ms-iso--ms-1900-2005, on $9^{\text {th }}$ September 2012.

Endsley, M. (1995). Toward a theory of situation awareness in dynamic systems. Human Factors: The Journal of the Human Factors and Ergonomics Society, 37(1), pp.32--64.

Fontaine, Rodrigue, and Kh halīq Aḥmad (2011). Management From An Islamic Perspective, Malaysia: Pearson.

Gibb, A. and Scott, M. (1985). Strategic awareness, personal commitment and the process of planning in the small business. Journal of Management Studies, 22(6), pp.597--631.

Hoff, W. (1970). The importance of training for effective performance. Public health reports, 85(9), p.760.

Huber, O. and Seiser, G. (2001). Accounting and convincing: The effect of two types of justification on the decision process. Journal of Behavioral Decision Making, 14(1), pp.69-85.

Lederer, A. and Mendelow, A. (1988). Convincing Top Management of the Strategic Potential of Information Systems. MIS Quarterly, 12(4).

Leonard, D. and McAdam, R. (2003). Corporate social responsibility. Quality progress, 36(10), pp.27-33.

MACS (2013). Transcript of interview- Interview session conducted on $17^{\text {th }}$ October 2013- Interviewee/respondent was the Manager of Service Monitoring Division at Malaysia Airport Consultancy Services (MACS).

Malaysiancertified.com.my,. (2015). Malaysian Certified. Retrieved 16 February 2015, from http://www.malaysiancertified.com.my/QMSCert.aspx?company=\&scope=\&standard=2700\&cyear= $\&$ status $=\&$ country $=\&$ state $=\&$ licenceno $=$

Mazzucato, M. 2002. Strategy for business. London: Sage in association with the Open University

Porter, M. E. "What Is Strategy?" Harvard Business Review 74, no. 6 (November-December 1996): 61-78.

Reliancestandards.co.uk. (2014). Importance of Standards. [online] Available at:

http://www.reliancestandards.co.uk/importance-of-standards.html [Accessed: 10 Feb 2014]. 
Qur'an. Undated. English translation of the Noble Qur'an. Translated by Al-Hilali,

M.T. \& Khan, M.M. Saudi Arabia: King Fahd complex for the printing of the holy Qur'an.

Sarion, Arbain, and Ummi Salwa Ahmad Bustamam. 'Crafting Strategy Towards Achieving The Certification Of Shariah Compliant Quality Standard, MS1900:2014: A Case Study At JPPF, USIM'. Seminar Pengurusan Kualiti Islam. 2014. Print.

Sherry, R. (2013). Customer-supplier relationship quality can drive success. [online] Value Chain Group. Available at: http://valuechaingroup.com/customer-supplier-relationship-quality-can-drivesuccess/\#sthash.1BtWHBoQ.dpbs [Accessed 4 May. 2014].

Siddiquee, N. A. (2006). Public management reform in Malaysia: Recent initiatives and experiences. International Journal of Public Sector Management. 19(4), 339-358.

SIRIM. (2013). Transcript of interview- Interview session conducted on $30^{\text {th }}$ August 2013- Interviewee/respondent was the senior auditor at SIRIM Berhad

Sun, H. (2000). Total quality management, ISO 9000 certification and performance improvement. Int $J$ Qual \& Reliability Mgmt, 17(2), pp.168-179.

Snyder, N. and Glueck, W. (1980). How managers plan - the analysis of managers' activities. Long Range Planning, 13(1), pp.70--76.

Syed Azauddin, S. (2005). Alternative Quality Management Standards Islamic Perspective (A Look At Their Rationale And Implementation). $1^{\text {st }}$ ed. Kuala Lumpur: Utusan Publications \& Distributors Sdn Bhd, p.1.

Utusan Malaysia, 27 ${ }^{\text {th }}$ March 2012, MACS pertama terima MS1900:2014. Accessed from http://www.utusan.com.my/utusan/info.asp?y=2012\&dt=0327\&pub=Utusan_Malaysia\&sec=Korporat\&pg=ko_0 2.htm on $9^{\text {th }}$ September 2012.

Yin, R.K. (2009). Case study research- Design and methods, applied social research methods series (4 ${ }^{\text {th }} \mathrm{Ed}$, Vol 5). Thousand Oaks, CA: Sage

10 Steps to ISO Certification | The British Assessment Bureau. [online] Available at: http://www.britishassessment.co.uk/articles/10-steps-to-iso-certification [Accessed: 10 Feb 2014]. 


\section{APPENDICES}

Figure 1: The flow of strategy implemented at first phase

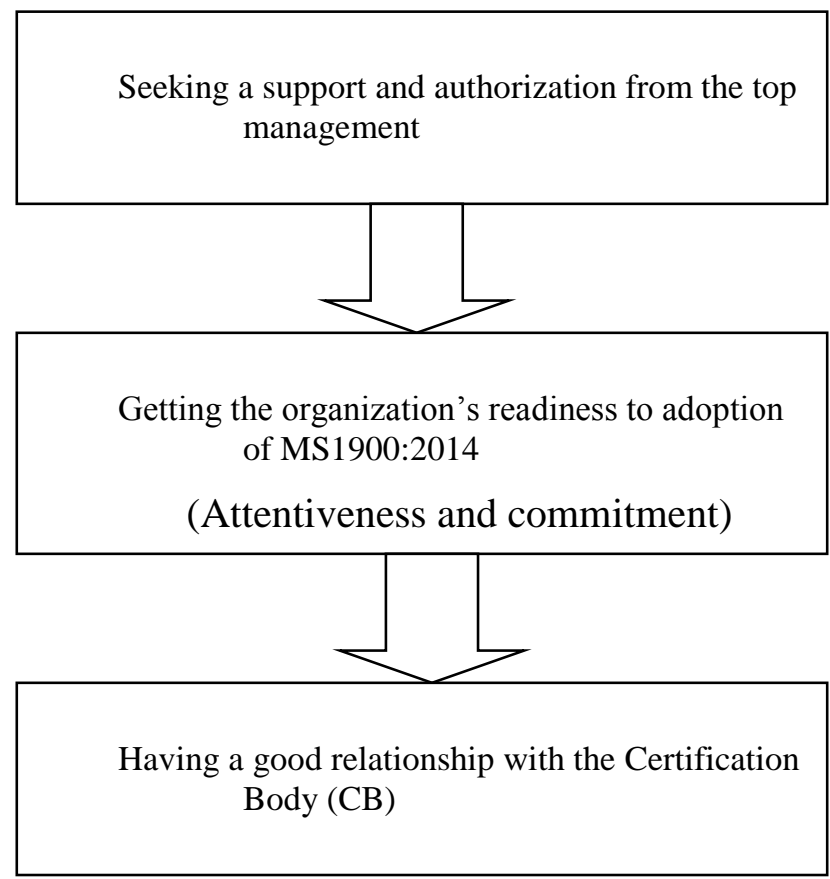

Figure 2: The flow of strategy implemented at second phase

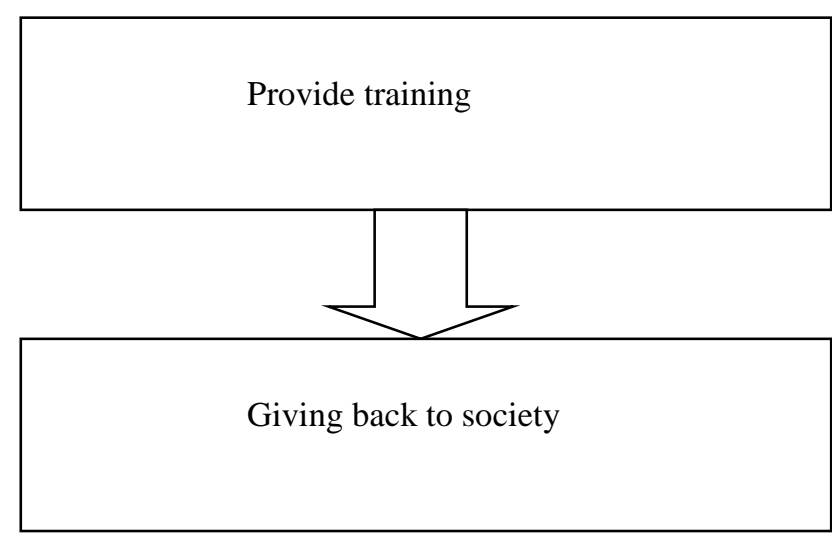

